\title{
TECHNICAL MANUALS READING STRATEGIES OF PRIMARY TEACHER TRAINEES
}

\author{
Jan Janovec ${ }^{1}$, Ivana Brtnová Čepičková ${ }^{1}$ \\ ${ }^{1}$ Jan Evangelista Purkyně University in Ústí nad Labem (CZECH REPUBLIC)
}

\author{
Eduport 5 (1) - Reviewed Papers \\ DOI: 10.21062/edp.2021.002
}

\begin{abstract}
Primary school teachers use a variety of visual materials in their teaching. In the technical field, it is often the diagrams, designs, and other types of illustrations the teachers accompany their instruction or facilitate practical work of their pupils with. Of course, primary school teacher trainees get acquainted with such materials in the higher education study process as well as within the school study placements. As the materials are intended to express a sequence of production steps, they are often drawn in series where the individual images are phased. Such arrangement is generally accepted as understandable and with greater potential to guide the readers' actions. Nevertheless, the question may occur whether the readers perceive such instruction materials in the same way they perceive ordinary images. This was assessed by, eye-tracking technology, the basic tool of the research, which analyses the respondents' eye movements when looking at images on the computer monitor screen. The technology can determine what the respondent is looking at while solving the task. The results in the form of qualitative and quantitative data were compared with the data taken with common images and text tasks. Statistically significant differences were found that are discussed in conclusion together with other findings.
\end{abstract}

Keywords: primary education, teacher trainees, eye-tracking, technical education, science education

\section{INTRODUCTION}

Assessment of motor eye activity with an eye-tracker, stationary or mobile, has not been a novelty in research anymore. The beginnings of working with the eye camera date back to the 1930s. Cinderella $(2018, p .15)$ mentions research pioneer Guy Buswell. As early as 1935, Buswell published the monograph "How People Look at Pictures," which contained records of watching pictures of more than 200 people. In the monograph, he presented a systematic assessment of respondents' eye movements when viewing more complex stimuli (Buschwell, 1935 cited by Cinderella, 2018). In the last twenty years, the intensity of research has expanded to many areas thanks to the development of technology. The eye camera is quite often used in marketing research (Van Reijmersdal, 2020; Ceravolo, 2019, Klimeš, 2001), in training or improving the performance of athletes (Panchuk, 2015; Discombe, 2015), in assessing the artwork perception (Massaro, 2012). It is also widely used in the military, neuroscience, psychiatry, and information technology. It is often used in reading research as well.

Eye-tracking (ET), an eye-tracking technology (Fig. 1), is also playing an increasingly important role in the educational sciences, as it makes it possible to penetrate learning processes. The most frequently researched phenomena that help to illuminate the steps of cognition - information processing of the observed phenomena include perception, measurement of performance and attention, representation of meaning, creation of concepts, learning strategies. Thus, we can use the camera to monitor the cognitive processes of the persons examined: what stimuli they were seeking, what order they were studying them in, how long they lingered on them, and whether they returned to them (Lukavský, 2005 cited Kekule, 2014). This applies to user-oriented research. Another option is evaluating existing teaching materials. Variants of multimedia teaching texts, textbooks, worksheets, cartographic materials, etc. can be compared. Testing the attention and perception of the text in connection with the design, the layout and the content of text backgrounds is one such example. Materials such as worksheets or textbooks are used as stimuli, which are then, subsequently, evaluated. The research focused on the perception and evaluation of multimedia teaching materials, usually on their visual and 
verbal content, on the technological tools and programming environments, is very common (Papavlasopoulou, 2018).

The above implies that many researchers see the great potential of ET in didactic research. History education didactic offers an example of the ET application in the subject didactics: Labischová (2015) examined the influence of a specific structuring the analysis of a historical caricature on the quality of its interpretation by the respondents. In the didactics of physics, we find research aimed at monitoring visual attention to relevant parts of selected diagrams among those respondents who correctly and incorrectly answered questions involving certain physical issues (Madsen, 2012). The research in the didactics of physics also monitored what the respondents - students do during a typical science study activity, i.e. while studying examples. It also dealt with the measurement of the time spent by the respondents over processing conceptual and mathematical information within certain examples. They also assessed whether the guidance provided to students about the objectives of the study activity affects the relative attention paid to conceptual or mathematical information, and investigated what the participants learned from the study activity (Smith, 2010). Kekule (2015) presented the results of research aimed at finding out the students' attitudes applied in solving problems related to graphs demonstrating the dependence of kinematic quantities on time. One of few studies has been devoted to primary school pupils. The psychological-didactic experiment carried out by Svatoš (2017) aimed at the perception and understanding of the visual parts of textbooks among first-year pupils. Among other things, the research showed that younger school pupils prefer visual materials depicting reality as accurately as possible.

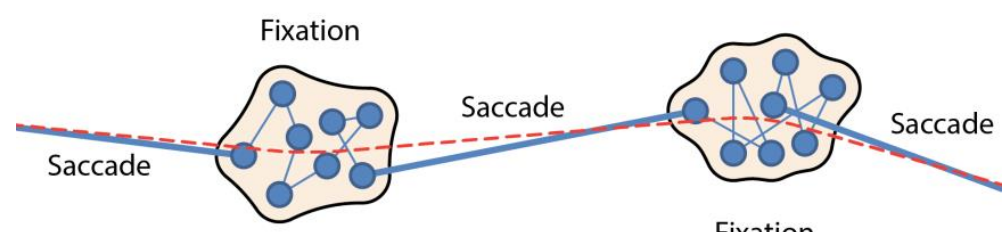

Fixation

Fig. 1 The trajectories of the eye gaze consist of fixations and saccades. When one concentrates on something interesting, the eye around this area trembles. These micro-movements are abstracted into fixations. Conversely, saccades occur when the focus shifts to another area of interest. (Krueger et al., 2016)

The use of this research method concerning actual practical activities is relatively scarce. Yu-Cin Jian (2021) is one of the researchers who focused on how students engage in the learning process following the combination of reading scientific articles and manual manipulation of a pulley system. Students, divided into 4 groups, worked with the texts ( 2 groups), with a difficult and simple text, then they wrote down their conclusions. The other two groups read the texts again (the difficult and the simpler text), this time the respondents could meanwhile manipulate the pulleys accordingly. The technology of ET in the field of science and technology education (in terms of technical and practical activities) has not yet been sufficiently represented in the research. In the presented case study, the authors thus attempt to set a basis for further research within a similar, but broadly conceived research survey.

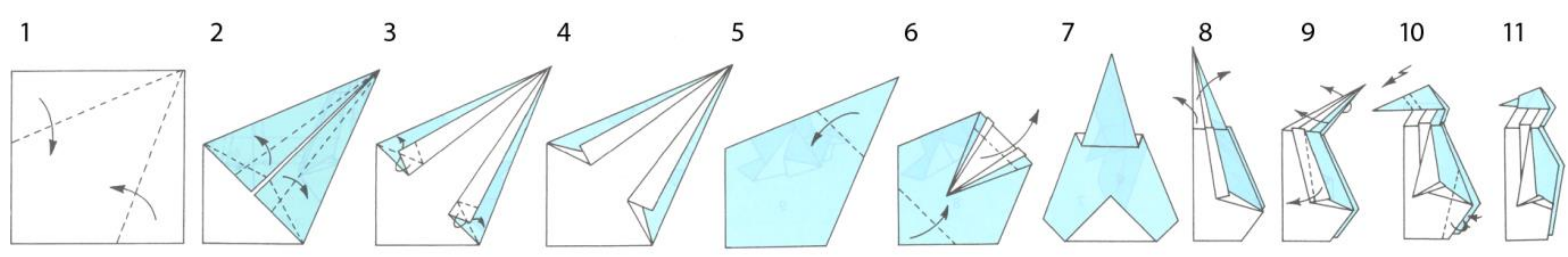

Fig. 2 Example of a pictorial instruction in a primary school textbook, paper model - penguin (Kociánová, 1997)

\section{Picture materials}

Science textbooks contain two essential components, i.e. verbal and pictorial. Research on comprehension of teaching texts has had a long tradition. Less frequent has been researching on understanding non-verbal elements of textbooks or different teaching materials, such as illustrations, graphs, diagrams, designs, 
photographs. Research in this area focuses on the frequency of occurrence of graphic components and their structure (Šimík, 2014) and also on the assessment of visual components concerning the text (e.g. Slough et al., 2010). Studies are showing that the image components improve learning (Butcher, 2006). Other results indicate that students may pay little attention to illustrations and rather underestimate their importance in the learning process (Schroeder et al., 2011). Mason (2015) states that the importance of illustrated text over nonillustrated text depends on the successful integration of verbal and graphic information.

However, theoretical and research work hardly deals with pictorial designs formed as a succession of individual phased depictions showing the chronology of the creation of a given object. According to Mareš (1995), they can be included among pictorial materials with the so-called organizing function, goals of which are transforming the students' so-called declarative knowledge into the procedural knowledge and appropriate arrangement of their knowledge or concepts and their mutual connection with reality. In practice, the pictorial designs are relatively common, they appear in textbooks (Fig. 2), in worksheets, and can be found elsewhere in a production process and in everyday life, e.g. pictorial instructions for assembling furniture.

\section{METODOLOGY}

\section{Participants}

The respondents of the research were a total of ten $4^{\text {th }}$ year primary teacher trainees, aged 22 and 23 , nine women and one man. Four female students took part in the first part of the survey, the rest of the students responded in the second part of the survey. Because in the last three years or more, all participants have undergone the same education, a similar perception of visual materials and a reasonably developed ability to read visual - technical instructions could be assumed. All the participants had good vision and had been calibrated for eye tracking. Two participants wear glasses, which was not manifested during the calibration or the measurement.

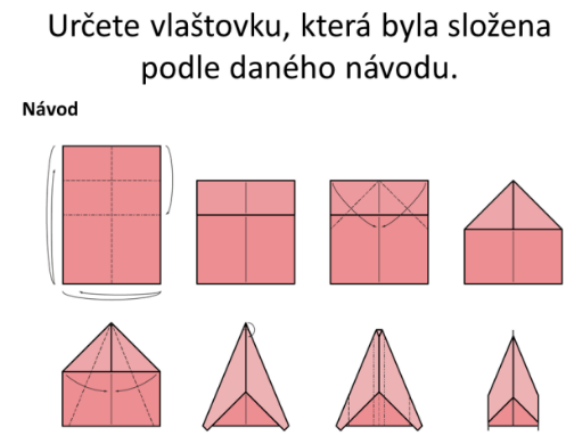

Fig. 3 Paper puzzle - airplane

„Specify the paper airplane model folded according to the instructions. “ „Determine the percentage of the area in all countries
Určete jaké procento rozlohy všech zemí světa
zaujímá stát, který je pátý největší na světě.

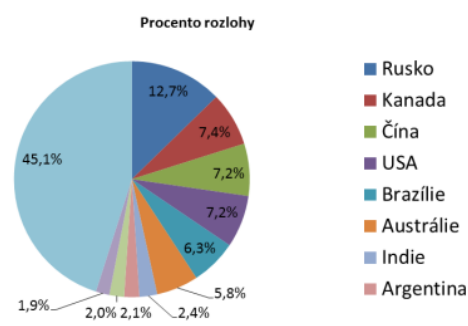

Fig. 4 Pie Chart Example "Determine the percentage of the area in all countries
in the World that is the fifth largest country in the world."

\section{Material}

The main subject of the research was technical visual picture instructions in the field of practical activities. In the first phase of the research, sequences of images to assemble a paper swallow (Fig. 3) were used. It is a simpler picture tutorial, that has a total of 8 steps. These were displayed in two rows to fill the entire screen and thus make the eye movement resolution as accurate as possible. A task from geography with the data represented by a pie chart (Fig. 4), was used as a control display. Pie charts are a widespread way of displaying data within natural sciences, even though there are reasonable reservations about their use for slower and less accurate reading of information. Nevertheless, it is still received relatively positively by readers and rated as slightly more enjoyable (Siirtola, 2019). Based on the results of the first part of the research, a change was made to the examined image materials. The research focused only on technical picture instructions, intending to display the sequences of pictures in one horizontal row and avoid splitting them into two rows (Fig. 5).

The individual paintings in Tobia Studio form a complete linear sequence, which the respondent gradually goes through and consequently solves the assigned tasks. There are several options for transitions between the slides, such as "fixed time", "mouse button" and "key on the computer keyboard". The fixed time cannot be used due to 
different lengths of task solutions in individual respondents. Following the previous experience, the use of the mouse button has also been abandoned. If the respondents stop holding the mouse during the measurement, they are very likely to leave the screen with their eyes to locate it, reducing or completely invalidating the measurement results. Subsequently, the cursor would not display during the measurement. Also, a higher resolution was used to make the most of the maximum area provided by the software and hardware. The used Tobii Studio software displays images in the given configuration by their resolution, due to the used monitor FullHD. To cover as large an area as possible, images with resolution that was or approached $1920 \times 1080$ px were used.

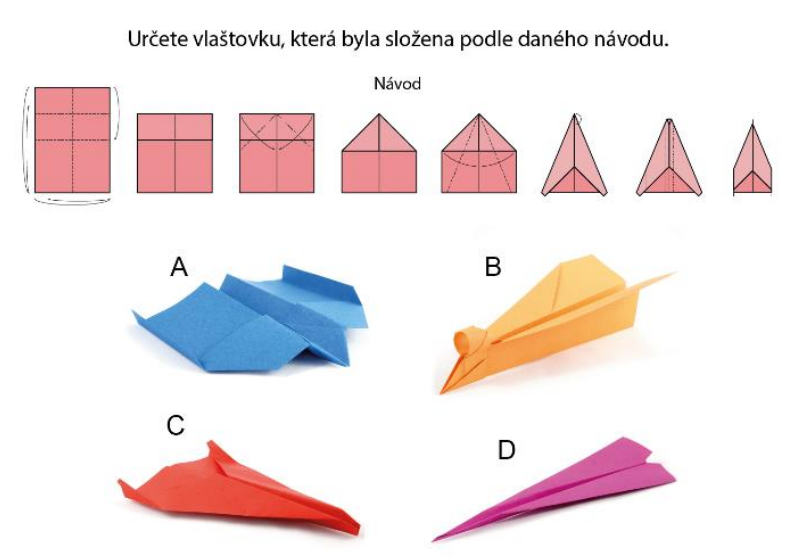

Fig. 5 Imaging used for the second phase of research "Specify the paper airplane model folded according to the instructions. "

\section{Apparatus and procedure}

The Tobii Pro X2-60 eye tracker with a sampling frequency of $60 \mathrm{~Hz}$ connected to the computer, the experiment was controlled by, was used to record the participants' eye movement. A 24-inch monitor the tracker was attached to, was used to display experimental stimuli to participants. The monitor was positioned approximately $60 \mathrm{~cm}$ from the participants' eyes, which is the distance the eye tracker shows the greatest accuracy in - i.e. about $0.4^{\circ}$. (Tobii Pro, 2021). The participants could move their heads and eyes during data collection freely. They changed the individual slides using the mouse or keyboard. The Tobii Studio software installed in the connected computer was used to store and analyze the respondents' eye-movement data.

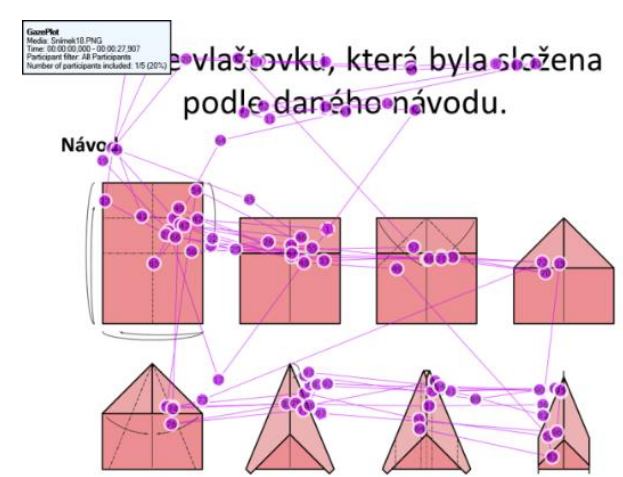

Fig. 6 Gaze plot 1.1

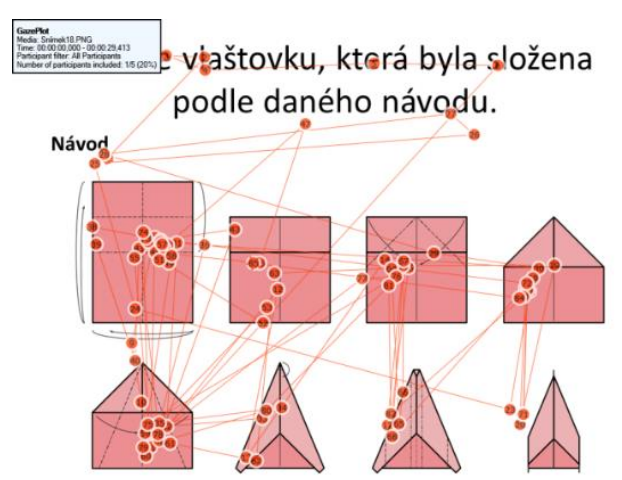

Fig. 7 Gaze plot 1.2

To minimize the respondents' distraction while solving the tasks and ensure their view would not have to leave the screen even when evaluating the tasks and giving answers, verbal answers were chosen. Although Tobii Studio allows questionnaire creation and administering answers, this was found to be unfounded. Olympus WS-853 dictaphone with mp3 recording were used to store the answers. The dictaphowasas started by the researcher prior to each respondent's measurement and ibeforeed on throughout the whole procedure. Information concerning respondents answers and opinions can be retrieved following synchronisation with Tobii Studio-processed eye-movement recordings. 
Camera recording provides an even more complete picture of the measurement. The GoPro 8 camera was used in the widescreen recording mode, which allows capturing the image on the computer screen, the face and the eyes, and thus the direction of the respondent's gaze. The camera was used to eliminate measurement errors if respondents looked outside the measurement field, as well as to backup in the event of a dictaphone failure or any error in the operation of the used equipment.

\section{DATA ANALYSIS AND RESULTS}

Both quantitative and qualitative approaches were used to answer the research questions. The main research question of the survey was whether and the view of the pictorial instructions differs from the view of other display types used in education. The aim was to find (qualitative or quantitative) characteristics typical for the technical pictorial instructions that distinguish them from other types of displays. The data exported by the Tobii Studio software were evaluated, both in the form of various graphic displays and videos and in the form of raw statistical data in a table of, regarding the amount of the obtained data, approx. fifteen thousand lines.

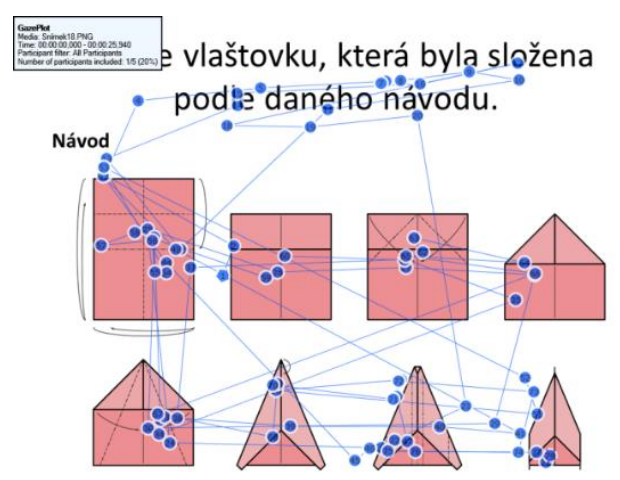

Fig. 8 Gaze plot 1.3

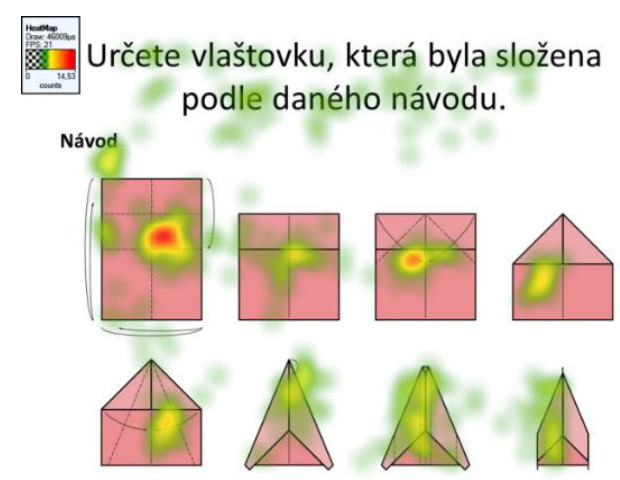

Fig. 9 Heat Map 1.1

"Specify the paper airplane folded according to the instructions. " „Specify the paper airplane folded according to the instructions."

Before performing numerical and statistical analyses, a qualitative survey was conducted based on empirical observations on individual Gaza Plot and Heat Map diagrams (image output of fixation allocations overlapping image of the problem to be solved) to examine possible group patterns. The output of the Gaze Plot gradually displays the individual respondents' gazes on the area of the image and numbers them. It is thus possible to read the order and the logic of reading the information. As shown in Figures $6-8$, in this case, there is no uniform strategy for reading the technical pictorial instructions. The expected predominant horizontal right-toleft approach (Fig. 6) was certainly not the only approach. Eye movement was also recorded, that studies the instructions mainly in the vertical direction (Fig. 7) as well as the approach where several movements saccades - are diagonal, not only during the logical transition from top to bottom row according to the order of steps when folding the paper plane, but also gazes are denying the logical process of model building (Fig 8). The informative value of the so-called heatmaps turned out to be lower in this case. It does not display the fixation order, only the length of time the respondents' gazes remain in place. The first, third, and fifth display differ slightly from essentially the same amount of time the respondents fixed their gaze on each image. This is most likely because the steps in question represent more complex paper folds over larger areas (Fig. 9).

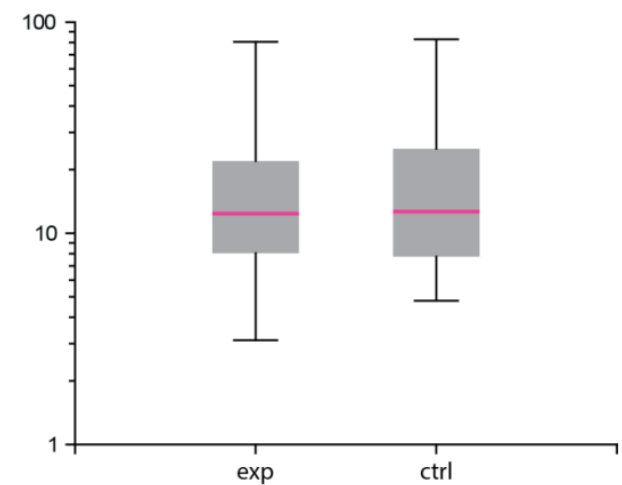

Fig. 10 Distance of saccades

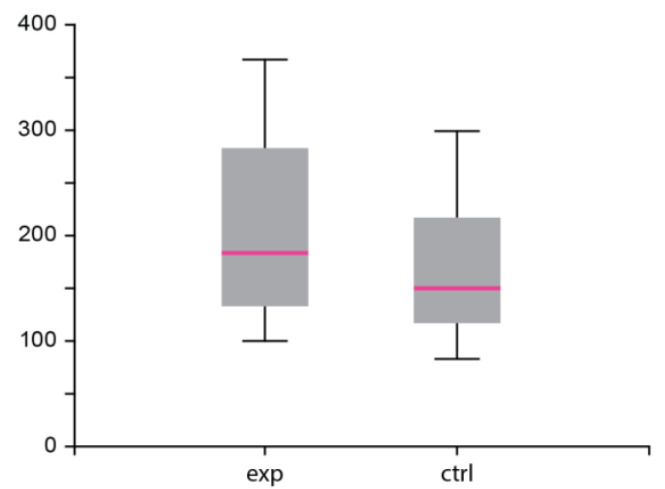

Fig. 11 Duration of gaze fixations 
Quantitative methods were also used in the first phase of the survey. From the obtained exported data, the data on the distances of saccades and the lengths of gaze fixation at the images were extracted. Two hypotheses were set up for both main monitored variables. Hypothesis $\mathrm{H} 1$ - There will be a statistically significant difference between the saccade distances of individual respondents' gazes at the technical pictorial instruction and control displays, and Hypothesis $\mathrm{H} 2$ - There will be a statistically significant difference between fixation times of individual respondents' gazes at technical pictorial instructions and control displays.

The null and alternative hypotheses were set up for both basic hypotheses ( $\mathrm{H} 1$ and $\mathrm{H} 2$ ), tested using a t-test, and, since the normality of the data was not confirmed in any case, the non-parametric Mann-Whitney $U$ test was also applied. NCSS software was used. In the first case, both the mean values and the median distance of the saccades in the experimental sample are smaller than in the control sample. However, the null hypothesis was not statistically rejected by any test at the set level $p=0.05$. The given differences must be considered statistically insignificant and the null hypothesis, there is no statistically significant difference between the saccade distances of individual respondents' gazes, must thus be considered valid (Tab. 1, Fig. 10).

Tab. 1 Measured values of quantitative survey

\begin{tabular}{ccccc}
\hline Measurement & $\mathrm{n}_{\text {exp }} / \mathrm{n}_{\mathrm{ctrl}}$ & $\overline{\mathbf{x}}$ & $\tilde{\mathbf{x}}$ & p-level \\
\hline Distance of saccades* & $1686 / 1240$ & $16,79-18,73=-1,94$ & $12,39-12,67=-0,28$ & 0,274 \\
Fixation times ** & $130 / 99$ & $221-183=38$ & $183-150=33$ & 0,009 \\
\hline
\end{tabular}

Legend: $\mathrm{n}$ - number of measurements, $\overline{\mathrm{x}}$ - arithmetic mean, $\tilde{\mathrm{x}}$ - median, ${ }^{*}$ in $\mathrm{mm},{ }^{* *}$ in $\mathrm{ms}$.

For the duration of gaze fixations, the longer mean value and the median were evaluated in the experimental sample. As in the first case, the normality of the value distribution was not confirmed, so the non-parametric Mann-Whitney U-test was applied. The difference between the means and medians of the measured values was positive in this case, the null hypothesis was rejected at the significance level $p=0.05$, and the alternative hypothesis was accepted, i.e. there is a statistically significant difference between the fixation times of individual respondents' gazes at technical pictorial instructions and control images (Tab. 1, Fig. 11).

For the second part of the research, the display of the sequence of paper model production in one vertical row was chosen to suppress the possible influence of the layout in two or more rows on the reading order of the instruction. Empirical observations were focused only on the Gaza Plot maps to identify possible patterns of instruction reading. The results in this section rather confirm the conclusions of the first part of the research, while the distribution of the individual images into one row did not lead the respondents to a uniform reading scheme, but had a positive effect on the reading and evaluating Gaza Plot diagrams. Specifically, the following pictorial instruction reading strategies have been identified. On the one hand, a strategy with a predominant study of a series of images according to the paper model construction chronology, after which the respondent begins to turn his gaze to the area in search of an answer to the given problem, E.g. the diagram in Fig. 12 . In some cases, the gazes are present by which the respondent returns to the instructions and checks his answer, comparing specific characteristics from all images or also from the text of the task.

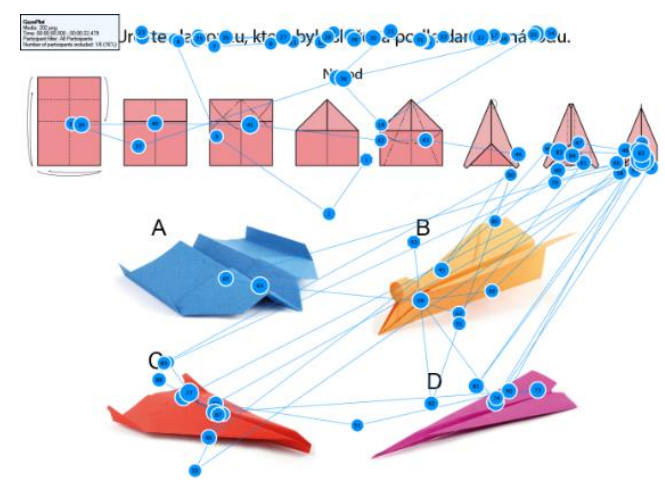

Fig. 12 Gaze Plot 2.1

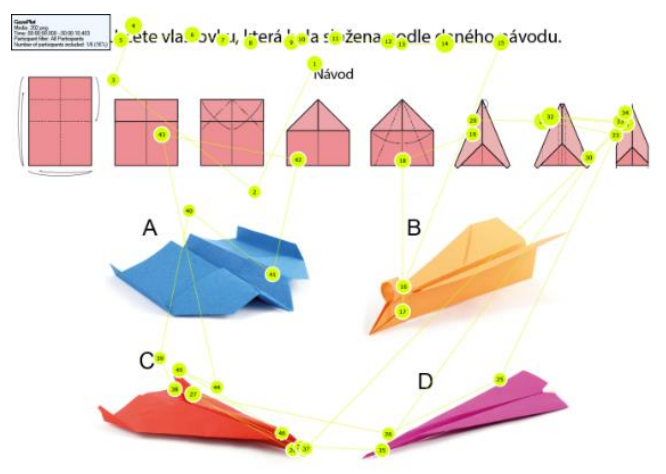

Fig. 13 Gaze Plot 2.2

"Specify the paper airplane folded according to the instructions. " „Specify the paper airplane folded according to the instructions. " 
On the other hand, an approach was identified in which the respondent, after reading the text of the task, does not go through the pictorial sequences of the paper airplane model construction and, in the first gazes at the images, he looks for relevant characteristics leading to the correct solution (Fig. 13). Here as well, gazes back at the pictorial sequences of paper model construction checking up the initially selected procedure can follow. Among these extreme resolutions, several approaches were identified that use elements from both, such as e.g. the gradual study of only some sequence of the instruction set, and the subsequent search for features in the offered solutions, multiple checks of the choice of the correct solution, etc.

\section{CONCLUSION}

The conducted survey is so far unique in the field of general technical education. The data obtained from the quantitative survey indicate that the primary school teacher trainees look the technical images differently than at the control images. The gaze fixation lengths proved to be longer, and there was no statistically significant difference in eye movements - saccades. It can be said that the connection with the statement has been confirmed that students generally pay more attention to selected options than to rejected alternatives and tend to spend more time researching relevant factors than the irrelevant ones. (Tsai et al., 2012)

During the testing, a requirement arose for the respondent to understand as soon as possible a sequence of steps leading to the production of a particular product was in question. Arrangement of individual images can have an influence on it, when the arrangements $2 \times 2$ (number of columns $x$ number of rows) or $3 \times 2$ are possibly the most misleading, and the arrangements $4 \times 2$ or, of course, $6 \times 1$, i.e. in a row, are the least confusing. This assumption has not been confirmed though. For the respondents, the methodological series is a sequence of steps of a process, even though it is not displayed in one row. On the other hand, the in-line display enabled the identification of different approaches to reading pictorial instructions. These approaches vary considerably, from relatively strict adherence to the sequence of images to the seemingly random study of pictorial instructions, based on the search for relevant signs of similarity and difference. Given the number of respondents, the following statement cannot be generalized in any way, yet the only mistake that occurred in solving the task was made by the respondent who chose this "loose" strategy.

Several identified strategies correspond to some previous findings, e.g. by Svatoš (2017), who examined the perception of visual materials by primary school pupils. He concludes that each pupil accepts and understands pictorial materials individually and this acceptance and understanding of pictorial materials is influenced by pupils' personality traits. On the contrary, the influence of gender on the way of observing images, which according to Sargezeh (Sargezeh et al., 2019) manifests in a lower ratio of fixation time compared to saccades, can be ruled out due to the design of the research, even though the majority of the respondents were women. A parameter that may further play a role is the complexity of the communicated information. Perhaps following Yu-Cin Jian's study (2021), the relative simplicity of the technical task of the paper airplane folding influenced the choice of various strategies, one of which did not lead to the successful solution. What factors influence the choice of the strategies for reading pictorial instructions consisting of a sequence of images, and whether they affect the in-image information interpretation. These may be an inspiration for further research, as well as investigating the reasons for the use of pictorial instructions in education.

\section{References}

[1] Buswell, G. T. (1935). How people look at pictures. Chicago: University of Chicago Press Chicago. Cit. In: Popelka, S. (2018). Eye-tracking (nejen) v kognitivní kartografii: praktický průvodce tvorbou a vyhodnocením experimentu. Univerzita Palackého v Olomouci pro katedru geoinformatiky.

[2] Butcher, K. R. (2006). Learning from text with diagrams: Promoting mental model development and inference generation. Journal of educational psychology, 98(1), 182.

[3] Ceravolo, M. G., Farina, V., Fattobene, L., Leonelli, L., \& Raggetti, G. (2019). Presentational format and financial consumers' behavior: an eye-tracking study. International Journal of Bank Marketing.

[4] Discombe, R. M., \& Cotterill, S. T. (2015). Eye-tracking in sport: A guide for new and aspiring researchers. Sport \& Exercise Psychology Review, 11(2), 49-58.

[5] Jošt J. (2017) Oční pohyby, čtení a dyslexie. Praha: Fortuna

[6] Kekule, M. (2014). Výzkum pomocí oční kamery ve fyzikálním vzdělávání. Scientia in Educatione, 5(2), 5873. https://doi.org/10.14712/18047106.107 
[7] Klimeš, J. (2001). Oční kamera v marketingovém výzkumu. Strategie, 9, 32-34.

[8] Kociánová, L. (1997). Praktické činnosti pro 1.-5. ročník základních škol: učebnice zpracovaná podle osnov vzdělávacího programu Základní škola. Fortuna.

[9] Krstić, K., Šoškić, A., Ković, V., \& Holmqvist, K. (2018). All good readers are the same, but every low-skilled reader is different: an eye-tracking study using PISA data. European Journal of Psychology of Education, 33(3), 521-541.

[10] Krueger, R., Koch, S., \& Ertl, T. (2016). Saccadelenses: interactive exploratory filtering of eye-tracking trajectories. In 2016 IEEE Second Workshop on Eye Tracking and Visualization (ETVIS) (pp. 31-34). IEEE. https://doi.org/10.1109/ETVIS.2016.7851162

[11] Lukavský, J. (2005). Sledování očních pohybů. [Bakalářská práce]. MFF UK, Praha. cit. In: Kekule, M. (2014). Výzkum pomocí oční kamery ve fyzikálním vzdělávání. Scientia in Educatione, 5(2), 58-73. https://doi.org/10.14712/18047106.107

[12] Mason, L., Pluchino, P., \& Tornatora, M. C. (2015). Eye-movement modeling of integrative reading of an illustrated text: Effects on processing and learning. Contemporary Educational Psychology, 41, 172-187.

[13] Madsen, \& Larson, Adam \& Loschky, Lester \& Rebello, N. Sanjay. (2012). Differences in visual attention between those who correctly and incorrectly answer physics problems. Physical Review Special Topics Physics Education Research. 8. 010122-1. 10.1103/PhysRevSTPER.8.010122.

[14] Massaro, D., Savazzi, F., Di Dio, C., Freedberg, D., Gallese, V., Gilli, G., \& Marchetti, A. (2012). When art moves the eyes: a behavioral and eye-tracking study. PloS one, 7(5), e37285.

[15] Panchuk, Derek \& Vine, Samuel \& Vickers, Joan. (2015). Eye Tracking Methods in Sport Expertise.

[16] Papavlasopoulou, S., Sharma, K., \& Giannakos, M. N. (2018). How do you feel about learning to code? Investigating the effect of children's attitudes towards coding using eye-tracking. International Journal of Child-Computer Interaction, 17, 50-60.

[17] Popelka, S. (2018). Eye-tracking (nejen) v kognitivní kartografii: praktický průvodce tvorbou a vyhodnocením experimentu. Univerzita Palackého v Olomouci pro katedru geoinformatiky.

[18] Prichard, C., \& Atkins, A. (2021). Evaluating the vocabulary coping strategies of L2 readers: An eye-tracking study. TESOL Quarterly, 55(2), 593-620.

[19] Sargezeh, B. A., Tavakoli, N., \& Daliri, M. R. (2019). Gender-based eye movement differences in passive indoor picture viewing: An eye-tracking study. Physiology \& Behavior, 2019(206), 43-50. https://doi.org/doi.org/10.1016/j.physbeh.2019.03.023.

[20] Schroeder, S., Richter, T., McElvany, N., Hachfeld, A., Baumert, J., Schnotz, W., ... \& Ullrich, M. (2011). Teachers' beliefs, instructional behaviors, and students' engagement in learning from texts with instructional pictures. Learning and Instruction, 21(3), 403-415.

[21] Siirtola, H. (2019). The Cost of Pie Charts. In 2019 23rd International Conference Information Visualisation (IV) (pp. 151-156). IEEE. https://doi.org/10.1109/IV.2019.00034

[22] Šimik, Ondřej. (2014). Analýza obrazových komponent v současných učebnicích př́rodovědy. Conference: Sapere Aude 2014 At: Hradec Králové

[23] Slough, S.W., McTigue, E. M., Kim, S., \& Jennings, S. K. (2010). Science textbooks' use of graphical representation: A descriptive analysis of four sixth grade science texts. Reading Psychology, 31(3), 301325. https://doi.org/10.1080/02702710903256502

[24] Smith, Adam \& Mestre, Jose \& Ross, Brian. (2010). Eye-gaze patterns as students study worked-out examples in mechanics. Physical review special topics. Physics education research. 6. 10.1103/PhysRevSTPER.6.020118.

[25] Svatoš, Tomáš \& Maněnová, Martina. (2017). Learning from Visual Materials: A Psycho-Didactic Experiment. Acta Technologica Dubnicae. 7. 10.1515/atd-2017-0003.

[26] Tobii Pro. (2021). Retrieved November 14, 2021, from https://www.tobiipro.com/ 
[27] Tsai, M. J., Hou, H. T., Lai, M. L., Liu, W. Y., \& Yang, F. Y. (2012). Visual attention for solving multiple-choice science problem: An eye-tracking analysis. Computers \& Education, 58(1), 375-385. https://doi.org/doi.org/10.1016/j.compedu.2011.07.012VAN REIJMERSDAL, Eva A., et al. (2020) Effects of disclosing influencer marketing in videos: An eye-tracking study among children in early adolescence. Journal of Interactive Marketing, 49: 94-106.

[28] Yu-Cin Jian (2021). Influence of science text reading difficulty and hands-on manipulation on science learning: An eye-tracking study. Journal of Research in Science Teaching published by Wiley Periodicals LLC on behalf of the National Association for Research in Science Teaching. https://doi.org/10.1002/tea.21731 